Received December 3, 2009

Revised February 18, 2010

Accepted April 2, 2010

\title{
South Korea's Scramble for Africa: Complexities and Implications
}

\author{
MARK CURRY ${ }^{* * * *}$
}

South Korea has recently made agreements to secure largescalc land deals in Tanzania, among other places, to secure cheap, long term agricultural supplies. Having limited experience in Africa, the potential for problems with Korea's partners is great. The feasibility, desirability and legitimacy of such projects must be examined to forestall difficulties. Africa's volatility and Tanzania's complex historical context likewise need to be understood alongside Korea's own history of colonization if its businesses are to be involved in the appropriation of Tanzanian indigenous people's land. Also, Korea's geopolitical standing and emergence as a developed country are implicated by such ventures. Significantly, securing future food resources by controlling large territories in distant continents is relevant to any discussion of Korea's security and international relations.

Keywords: Food Security, Land Deals, Agriculture, Appropriation, Indigenous Peoples Rights, African History, Neocolonialism

- The author would like to thank the ISR reviewers for their invaluable comments and suggestions. In addition, he is grateful to Professors Eun Mee Kim and Brendan Howe for the reception at ISR and the efforts of the institute. John Mirikitani and Airah Cadiogan were kind enough to read the manuscript and assisted with research and editing. The ISR staff members, also, were extremely helpful.

*Visiting professot at Hallym University in Chuncheon, Seoul, Korea; E-mail: curry.mark@gmail.com 


\section{INTRODUCTION}

S outh Korea's recent attempts to secure sizeable land deals in Madagascar and Tanzania in eastern Africa, and elsewhere, for agricultural purposes are part of a new initiative reflecting concerns about food security and China's ambitions and influence (Bates, Huang and Morrison 2007). Yet, with Korea's limited experience or presence in Africal it is likely that problems for both Korea and African partners may occur, as was the case in Madagascar in early 2009. To identify the scope for potential problems requires greater consideration of history, mutual geopolitical standing, and timing, more so evident now. Also, it must be asked to what extent long term land leasing is feasible, desirable or ultimately legitimate for Korea. Understanding Africa as a complex and volatile continent is critical, as is Tanzania's transition from colonized territory to independent socialist state to its more recent market-driven quests for development. Such issues will eventually be brought to bear on Korea's hopes of a special relationship in Tanzania and in the region. More specifically, the potential for land appropriation in Tanzania at the expense of its indigenous peoples questions Korea's increasingly growing role as an arbiter of smaller nations' national and geopolitical interests. Real land use at home and abroad, the emergence of Korea as an aid donor rather than recipient (Kim and Lee 2009), and even the bid to host the 2018 Winter Olympics ${ }^{2}$ are relevant to whether Korea can and should secure future food resources by controlling land in distant continents. Such issues affect Korea's security, diplomacy, and global aspirations.

\section{LITERATURE REVIEW}

Korea's quest to secure cheap agricultural land abroad following the volatility in international commodity markets since 2007 is recent and historically novel. Deals made, broken, and elsewhere remade have proliferated rapidly since 2008 , which has given little opportunity for scholarly assessment of the effects and implications. This paper is thus principally a case study from available resources of these new developments. While neocolonialist critique underpins many of the readings used here, which offers scope for specialist qualitative and quantitative research, as yet no systematic study of Korea's involvement in international agricultural land acquisition has been made.

Well known work relevant to this paper and of use for further direction in this field follows Dependency Theory for understanding the implications of inequalities in the economic relationships being initiated with Korea as the dominant partner. This theory posits that resources are removed from the poor peripheral regions to the wealthy core in the world economic market system. In effect, harnessing poorer states into the world system for their own benefit is disingenuous 
since the imbalances in the relationship preclude benefits from being equal or equally shared. The peripheral partner becomes a source of relatively inexpensive raw materials, cheap labor, a market for relatively expensive consumer goods, and a repository or dumping ground for old technology and waste products. ${ }^{3}$ The peripheral nation or region lacks the infrastructure, technology, or profile in media, finance, and education, at home or abroad, to counter or negotiate the process of its coupling into the world system. It becomes dependent on the system it is locked into and lacks the means to decouple from or gain more equal access to it.

However, Korea, in terms of the theory, is not strictly part of the wealthy and powerful core. It is what Immanuel Wallerstein's (1976) World System Theory calls the semi-periphery, and may more accurately be considered a semi-peripheral nation with core aspirations. The semi-peripheral state acts as core to the periphery and as peripheral to the core. The semi-periphery nominally retains a status independent of traditional post-colonialist relations, and associated tensions or suspicions, either by geographical distance or by having itself formerly been a colonized state. Nevertheless, within the world market economy, the semi-periphery is a proxy core to the periphery and the consequences of agreements and relations are recognizably similar in many cases: the enormous differences between nations and the imbalances entailed are worked out as the commoditization of peripheral labor and land, the stripping of resources of intrinsic, cultural, historical value, and processing them into products for exchange.

From these theoretical perspectives, the terms of the deals considered in this paper such that Korea, as a formerly poor nation with a post-colonial history of guarding its own markets, would never have found them domestically acceptable had they been exacted on Korean land and resources. Yet, it is likely that ordinary Korcans, if at all acquainted with such deals, would feel pride in their nation's growing prestige and geopolitical standing. This structure of knowledge can be considered under the rubric of Edward Said's (1978) concept of "Orientalism", a foundational theory for studies in neocolonialism. Said points to erroneous assumptions underpinning Western historical attitudes toward commodity-rich, economically poor regions of the Orient. In effect, the Orient is a screen onto which the (Western) Orientalist can write his own narrative and self-affirmation, beginning the process of imposing transformations with the introduction of large scale technological and economic superiority. By substituting African and Africanist for Said's terms, the relevance for emerging relationships between the semi-periphery and the periphery with respect to 'venture agriculture' can be identified more effectively.

An additional move of self-affirmation is to determine that the land and/or properties earmarked for appropriation have no history or formal ownership structure, that they are strategically suitable for immediate development with available cheap labor, ready to be harnessed into the new management structure, and that a foreman class is willing and equipped to ensure the supply and orderliness of labor. Africans, in terms of this narrative, are either negligible or deal enablers. 
Over time, the Africanist updates and shapes the narrative, establishing himself as cohesive, organized, time-conscious, and dependable; whereas the African is seen and taken as the binary opposite of these terms. This practice reaffirms for the Africanist the very importance of his implantation and the necessity of the relationship, no opposition to which is considered valid.

Whereas the African at first has no resistance to the new order, over time she learns the imposing discourse and develops a resistance to it that becomes, as Frantz Fanon theorized in The Wretched of the Earth (2001), a factor in the move to a new nationalism in which the citizens unite in opposition to outside imposition, from which base a new liberation becomes possible. The risks, thus, for Korea in initiating such capital projects in Africa are greater for beginning the enterprise as an 'absolute other' in terms of purpose, priorities, historical relations, language, temperament, culture and geographical distance. The relevance of Fanon's thesis is exemplified by Korea's engagement in Madagascar.

\section{CASE STUDY}

\section{The Madagascar Deal}

In mid-March 2009, Madagascar's new president, Andry Rajoelina, broke an agreement with South Korea's Daewoo Logistics stating that the will of the people had not been endorsed 4 . The deal, brokered under the ousted government of Marc Ravalomanana, would have allowed Daewoo Logistics the rights under a 99-year lease to 1.3 million hectares, approximately half of the country's arable land 5 . Signed during a period of global commodity price increases and with a view to Korea's longer term food security, the plan was to produce palm oil and corn ostensibly for livestock feed, instant noodle production and bio fuels. The potential for civil war in Madagascar was averted by regime change and, as a related factor, the land deal was annulled two days after Rajoelina took power. Daewoo Logistics, however, unable to honor its debts, declared bankruptcy in Seoul in July and in New York in September (Kary 2009). The Daewoo deal was hastily set in motion and, at least from the point of view of its designers, brokers and principals, believed to be both relatively inconspicuous and unproblematic. This is important when it comes to the case, reported by the $\mathrm{BBC}^{6}$ in African news services online, ${ }^{7}$ of a following land deal putatively agreed to by the Tanzanian government and a South Korean state-run enterprise, the Korea Rural Community Corporation (KRC), in September 2009.

\section{The Tanzanian Deal}

The agreement, which followed Prime Minister Mizengo Pinda's visit to Korea 
in early September 2009, was first announced in the media by a KRC representative, Lee Ki-Churl. Initial reports did not disclose the location of the project. Korean and the Tanzanian media later established that the plan envisages an initial investment of 83 million dollars to develop 100 square kilometers near the coast (10\% of the proposed area) in the state of Pwani in Rukwa and in the Rufiji river basin for mining, agriculture and the processing of agricultural products such as canned foods, wine and starch. 8 The feasibility study was to be concluded in 2009 and work to begin in early 2010. The lease is, in part, provisionally for 100 years, nominally for free with the costs of development to be borne by the Tanzanian party, with other investment costs settled in terms of mineral extraction rights.

Significantly, the deal directly follows the aftermath of the failed project in Madagascar and would seem to have been set up in a similar way: agreements were made with select senior officials but did not include consultation with the Minister of Agriculture, Steve Wassira, and the Tanzania Investment Centre. Thus, the suddenness of the PR announcement, the expected speed and mode of implementation, and the results of the Madagascar deal indicate a problem of due diligence, and the potential for unforeseen problems to occur. This point will be considered more closely in the context of regional political conditions and Tanzanian history.

A difference between the two projects is of scale: Pwani's 1000 square kilometers is roughly $10 \%$ of the landmass that was under lease proposal with Madagascar. This may have been to reduce risk, input costs and attention to the deal. Or it may be that less land is available for leasing since Tanzania's president, Jakaya Kikwete, allegedly offered 10,000 hectares (of a requested 500,000 ha) under a 99-year lease to Saudi Arabia in April 2009.9 A second difference is that the public sector has taken the lead over the private sphere in the initial stages of the deal. Although Daewoo Logistics' ownership structure was always complex, as indicated by bankruptcy proceedings in Seoul and New York, it seems clear now that initiatives by the Korean government were the directive in the Madagascan venture, but are the principal force in the subsequent one.

Nevertheless, corresponding factors in the two cases include the location of the investment site on the eastern seaboard of Africa, and the concept of land development under external control as being unrelated to particular people and their history. It is not known which indigenous tribes in the Pwani state are likely to benefit from or be disadvantaged by the process. In light of comments made by Lee Ki-Churl, these questions do not seem to be relevant:

- Some African countries export fruit and import fruit juice $\cdots$ simply because their past colonialists did not teach them how to process food. We plan to set up an education centre for Tanzanian farmers in the food-processing zone in order to transfer agricultural know-how and irrigation expertise to them. ${ }^{10}$ 
In further unquoted material of the BBC, Yonhap, a Korean news agency, allegedly declared that the cost of development would be offset by mining rights for iron, gold and copper in other parts of Tanzania. This has additional effects of expanding the geographical and technical scale of the deal and giving first indications of other transformations to be imposed on local communities by the project, in the kind of process described by Edward Said in Orientalism (1978).

In the first instance, using proceeds from the primary production enterprise of mining to offset the costs of another, agriculture, directly contradicts Lee Ki-Churl's ideal of helping Tanzanians to help themselves in contradistinction to colonialist practices. Plausibly, Tanzania might benefit from the export of canned pineapples, for example, but it will likely have to import Korean cars and trucks for transport. Exporting iron ore and importing sheet metal is the colonialist bind in exemplification, and as Dependency Theory posits, so Tanzania's prospects from the deal do not at the outset look optimal. In other words, the plan runs the risk of being understood as neocolonialist. This presents a problem for a country such as Korea, which has its own difficult history under foreign occupations.

Secondly, it advances the prospect of a broad introduction of services and support for the Korean administration of the enterprise, which in turn would call for the installation of facilities to accommodate Korean workers, potentially including schools, churches, medical services, and social facilities. These services can offer menial employment to local Tanzanians but they are likely to be exclusively for the use of the Korean community, which then calls into question how benefits of investment accruing to the Tanzanians are to be properly accounted.

The Hanjin Heavy Industries construction project in Subic, Philippines, offers a corresponding case by which to consider this issue. Filipino laborers worked under ill-regulated conditions resulting in at least 20 deaths, while Korean engineers and managers were alleged to have entered and left the country on tourist visas (Sce 2009). Such a project appears to offer attractive employment opportunities for local workers but lacks a committed interest in their welfare. A paper by Cotula, Vermeulen, Leonard and Keeley (2009) for the International Fund for Agriculture and Development (IFAD) describes how contract terms typically for the benefit of the host nation are neglected once agreements are signed: there are few legal amenities for the redress of problems, little protection of the rights of host nation citizens involved in or affected by projects, and little transparency or oversight with respect to management.

Thirdly, it would seem from Mr. Lee's comments that the question of colonialism in Africa is not in itself a problem, but that its flaws could have been smoothly overcome had there been a better supply of educational and plant facilities. This indicates a lack of familiarity with local African history and begs the question of what international aid agencies have been doing for the past 40 years. But 
it more specifically suggests that Korea believes it has found the right trade-off between investing in and profiting from peripheral nations, and that this model will be successful in the future. Notably, the validity of the deals being decided is longer than many African countries were ever formally colonized. This leaves much scope for problems to arise that are invisible under the relatively simple constraints of commodity costs on international markets.

\section{SPECIFIC COST-BENEFIT IMPLICATIONS OF THE DEAL}

The anticipated undertaking is no less important than the haste in its implementation and the steering force behind it. The agricultural products expected to be produced for export include cooking oil, wine and starch. If food security is a major aspect of a deal's urgency, none of these products specifically alleviate such issues, let alone hunger or starvation. Conceivably, such goods are destined for local African consumption and are not specific products that are actually grown for export. If so, three cost-benefit issues become immediately apparent.

First, these "new and improved" goods may permanently change the tastes of local consumers. Lappé, Collins and Rossett (1998, 12) identify the use of wheat in several African countries in these terms: because it does not grow well in specific regions, it must be imported. However, tastes and marketing draw population groups to forego traditional dietary culture and strive to spend more on bread products.

Second, because of statutory health requirements and the demands of global supermarket groups for particular food quality standards in the importing-lease holding nation (Minten, Randrianarison and Swinnen 2005), inputs to product quality in the producing nation make the overall cost of production higher than that of local competition. The result is that more expensive "foreign" products locally produced saturate the market and crowd out community initiatives or traditional goods.

Third, in the case of wine production a particular irony presents itself: South Africa's "dop" system (payment for farm labor in wine) continued on some wine farms until the 1990s, creating generations of indentured alcoholics (London 1998). It would be in KRC's and Korea's best interests to forestall any such association with South Africa's apartheid legacy. In other words, active knowledge of African experience, past and present, can help to avoid obvious problems and be advantageous for Korea as it aspires to a leading position on the geopolitical stage.

One example in support of this point can be given by Kim and Lee's (2009) description of Korea's ODA status as a donor rather than recipient nation. Whereas the EU pointed to three major issues-fragmentation of ODA administration and control, the lack of legal frameworks in support of initiatives, and questionable 
evaluation systems for the effectiveness of projects-a similar critique could be applied to Korea's overseas land acquisition strategy. Acting coherently and transparently on deals in Africa can eliminate problems en route to building a dependable international profile.

\section{THE CONTEXT OF AFRICAN COLONIZATION}

While Europe's "Scramble for Africa" in the 1880s resulted in colonies of improbable political geographies, for example, formerly German South West Africa's straight frontier lines through to the Caprivi Strip, it also forged nations out of people in no way naturally allied to one another. Arguably the genocides in Rwanda from the 1960s to the 1990s had roots in Germany and Belgium's remotely decreed collocation in one territory of disparate peoples. Today, Zambia, a geopolitical leftover, comprises over 70 different ethnic groups, while Tanzania has around 120. Although both of these countries have had relatively peaceful post-colonial histories, this has not always been the case in Africa.

David Lamb's (1982) book, The Africans, covers the African crisis, particularly post-independence, in detail. From the Tubman regime in Liberia to the fall of the Emperor Bokassa in the Central African Republic to Idi Amin Dada of Uganda, the continent's progression in time has been littered with strong men eased into power, tolerated thus until expendable, and then abandoned while individuals, communities and institutions were crushed.

In 2008, Kenyan unrest saw thousands killed, while South Africa's violence against foreigners in the same year led to dozens killed and tens of thousands displaced. More recently, Guinean security forces killed over 150 opposition demonstrators and raped scores of women, while Gambia's president Jammeh announced in 2009 that his country would kill any human rights worker who tried to visit. The struggles in eastern Congo (Democratic Republic of the Congo) since 1998 have accounted for over 4 million lives to date, even as international celebrities make much of the disaster in the Darfur region of Sudan. These data in brief are significant for a number of reasons.

First, the problem areas are relatively near Tanzania. Secondly, they are not isolated but general, characterized by extraordinary violence, with the perpetrators enjoying relative impunity. Importantly, this has been a norm of life for generations in some cases: the acts of genocide in Rwanda alone began during the Hutu revolution between 1959 and 1963 (Brannigan 2007). The point is not that Tanzania is safe today and that this is adequate insurance for ongoing long term Korean investment, but that past peacefulness is like a "value at risk" banking model: it is only reliable up until the events of yesterday. To consider the cost and benefit risks for Korean enterprises in eastern Africa, Tanzanian and Korean geographical and historical conditions need to be compared. 


\section{CONTEXTUAL ANALYSIS}

\section{Geography and History}

Given Lee's (2009) report that the KRC project is slated for the Pwani state adjacent to Dar es Salaam in the eastern sector of the country, some data related to the state is relevant. According to the National Bureau of Statistics (NBS), Ministry of Finance and Economic Affairs of the United Republic of Tanzania, Pwani state's population was 992,000 in 2007, giving it a density of about 30 people per square kilometer for a 33,000 sq. km region (2008, 18). Meanwhile, the United States Department of State's Bureau of African Affairs (2009) states that the population density in Tanzania varies from 1 per sq $\mathrm{km}$ in the dry regions to over 50 per sq. $\mathrm{km}$ in the well-watered areas. Pwani is relatively well-watered with an above average population density. Consequently, while KRC might be able to draw on a steady supply of local labor, the possibility is equally strong that a significant portion of the indigenous farmers will be permanently and adversely affected by the lease project.

Secondly, overall life expectancy for Tanzania in 2007 was roughly 54 years for males and females taken together; the literacy rate, in addition, was around $70 \%$ (NBS 2008). Because of Pwani's proximity to DaresSalaam, the supply of information and movement of people is likely to be relatively high. Nevertheless, health issues and reliability may be problematic for long term investment: the Pwani HIV infection rate was about $5.4 \%$ in 2007, less than the national average but still significant, especially if underreported. Income nationwide, according to government statistics, was approximately 100,000 Tanzanian shillings per month (roughly equivalent at October 2009 exchange rates to 100,000 Korean won). In sum, Pwani probably acts as a feeder state for the capital, with significant loss of population due to the opportunities and amenities the city has to offer to those with energy, ideas, skills, intelligence and youth. Real incomes in Pwani are probably lower than those given here, especially in the more outlying districts.

A question for Lee $\mathrm{Ki}$-Churl and the KRC is which indigenous population groups would have to be dispossessed for development purposes, and would their existing water supplies be diverted from existing sources? Also, how much water would be needed and how much would then be available for local populations? Controversially, a contest over water could end up displacing the indigenous users, pushing them into more marginal areas and into conflict with other indigenous groups. Eventually, the scope for food catastrophe becomes multiplied. This is a point of real significance. In "World Hunger: Twelve Myths," Lappé et al. $(1998,17)$ make the following point:

- When people are denied the resources to grow or retain enough of their own harvests to meet family needs, and when only buying power-money 
-gives people claim to additional food, many will go hungry or even starve if their income falls or food prices dramatically rise.

To support this point, the authors cite Ireland's experience of famine in the mid-1800s in which millions starved or emigrated while food was being exported in large quantities to England. In other words, the prospect for food security today needs to he measured against the less comforting one of enduring historical infamy.

Regardless, Lee Ki-Churl's perspective is that such considerations and possibly affected populations are not relevant to the discussion. This would constitute the same kind of attitude that presumably caused rioting among the Madagascans. One complexity for the Korean 'venture agriculturalists' will be how to represent their nation, with its rigorous memory for its own colonial-era hardships, while employing in public language and attitudes comparable to those of Japanese officials and spokesmen prior to the 1905 Treaty. ${ }^{11}$

This is important, since just as the Japanese until the present have maintained their rights under international law of the Great Powers era, so it must be expected that agricultural business of the $21^{\text {st }}$ century will try to secure their investments in terms of signed trade agreements and contracts, despite the fact that such agreements tend to be short, vague and insubstantial, and that the scope for problems over the next 100 years is large and unpredictable (Cotula et al., 2009).

It can be noted that Japanese construction of railways in Korea to facilitate the transport of goods and services was already an undertaking as early as 1901 (Akira 2007), well before actual annexation. In other words, at the turn of the last century ordinary Koreans did not initially see what was likely to be the future of their country and their own roles in it. Seen in terms of business interests and investments, manual work on the peninsula was done by unskilled Korean laborers with oversight carried out by Japanese officials who had the power to maintain order and enact disciplinary measures on workers and citizens. The case of Kim Sang-do exemplifies these unhappy relations (Lankov 2008). Where existing Korean industrial concerns at home or in South East Asia make use of non-Korean labor, relations are frequently troubled (Moon 2000). However, building an industrial plant and undertaking huge farm leaseholds are quite different in the way they affect indigenous people and their culture. It is thus critically important that the KRC understands how to avoid obvious mistakes in the present and historical hypocrisy over the longer term.

Notwithstanding this cautionary remark, it must be clearly stated that differences exist between Korean interests in Tanzania and those of Japan on the Korean peninsula over 100 years ago. Principally, Korea does not envisage occupation of the whole country; second, no military presence of any kind is anticipated. Yet ways for the KRC to safeguard its interests and investments on so large 
a scale are not yet clear. A corresponding complexity is what to expect from the Tanzanians in the event of unforeseen problems. To consider this in more detail, Tanzania's past is informative as are recent changes in its land laws that have enabled large scale land deals with foreign enterprises.

\section{Politics and History}

Modern Tanzania was formerly part of British East Africa and before that German East Africa, an asset that began as a business charter in 1885 (Miller 1974 ) before becoming a protectorate and finally the colony known as Tangyanika, with borders fully defined only in 1910 . One lesson can be gained from considering the Tangyanikan people's response to German colonial excesses: a revolt in 1888 was put down with British support, then small scale guerilla struggles began in 1891 and continued until 1898. Later, an attempt to force cotton growing on the native peoples amid great and sudden changes to their social and natural environments caused the Maji Maji uprising: less than a generation after the start of the Scramble, African groups fought a sustained, general struggle in the belief that they were impervious to German bullets. The uprising lasted two years (1905-1907) before it was crushed with superior German weaponry (Haynes 2005).

These examples show how the resistance escalated over time, it antagonized the authorities, ignoring their superior force, and it used 'magic' under charismatic leadership as a way of drawing in supporters. This is relevant to the prospects for agricultural business in Africa. For the Koreans, should indigenous people's crops fail due to climate disruptions, pests or some 'act of god,' it would be politically difficult and practically risky to export food from Tanzania or charge international market prices for it. And it might be very hard to label resistance as terrorism.

A second lesson is Tangyanika's experience of World War I. At the time, the British to the north in Kenya were dismissive of African fighting ability and scorned the Germans under General von Lettow Vorbeck for giving rifles and training to African people (See Miller 1974). Vorbeck and his soldiers remained undefeated by the end of the war. In the final analysis, the Allies employed over a million people to hunt the Tangyanikan troops, of whom no casualty records were kept. This example reveals the African people's endurance, ability to sustain loss, and knowledge of their environment. Geographical surveys, feasibility studies and reliance on extraneous assurances are unlikely to supplant these aspects of life and work in Tanzania. Indeed, it is probable that Korean agricultural investors are not well aware of counter-mapping in Tanzania (Hodgson and Schroeder 2002).

Over the past decade, indigenous peoples, particularly among the Maasai in the north of the country, have been creating and defining their own maps precisely 
in counter measure to the dispossessing and debilitating effects of maps as laid out and handed down from the colonial to the post-independence era. The purpose of counter-mapping is to identify, outline and protect indigenous people's land rights and to store and manage local knowledge, resources, community skills and mobilization for conflict resolution and other purposes.

A third factor is the presidency of Julius Nyerere, who ruled the country from independence in 1963 until 1985. He resisted South Africa's apartheid regime, his forces eventually pushed Idi Amin from power, and he remains one of the few long-standing African leaders to have voluntarily stepped down from power. His memory as the Teacher ("Mwalimu") and Father of the Nation is still revered. Although his style of socialism would be better understood officially by North Korea, Nyerere is of fundamental importance to the modern nation and, publicly, officials still make association with his legacy. He formulated the idea in 1967 that Tanzanian land, as according to pre-colonial ways of life, had to be "held in common and for the benefit of all" (Kironde 2000, 152). In other words, a foreign entity seeking to introduce changes to the philosophy of the "Teacher" could find Tanzania an unpredictable place in which to work. Arguably, Tanzania's experience of relative peace despite limited prosperity owes much to the idea of an authentic African independence inspired and instilled under Nyerere. It may also explain to some extent why, as reported on the TANServe blog (2009), government officials firmly denied the reports of KRC's deal. In effect, Nyerere's legacy stands in contradistinction to economic relations under the logic of the international marketplace and the power of global business to couple peripheral nations to those of the core and/or semi-periphery.

At this point, the changes to land rights law in Tanzania can help to understand how a "land grab" (Food and Agriculture Organization 2009) by international speculators has come into existence. It should be noted that with the collapse of international financial markets from 2007 to 2009, pension funds, hedge funds, banks and rich world governments have urgent need to repair balance sheets, prospectuses and long run forecasts. Agriculture, as a commodity base, was long overlooked and currently the potential return on investment through complete control of the business supply line from crop planting to the shopping basket appears to be very compelling (GRAIN 2009).

How foreign investors could obtain Tanzanian land tracts and water rights nominally for free came about by the Land Acts of 1999. Robin Palmer (1999) of Oxfam considered two interpretations of the acts. Issa Shivji found that the majority of land users in the country, the small farmers, peasants and women, would probably not benefit because a significant shift in control had moved to the government as represented by the Commissioner of Lands and, with "radical title," by the office of the President. These powers would become concrete and irreversible over time. She felt that village management had been taken from the villagers themselves and that they now functioned as mere agents. 
Moreover, a "land market" "could well result in poorer people in villages loosing (sic) their lands" (Palmer 1999, 4).

Issa's counterpart, Liz Wily, on the other hand, was confident that fears of foreigners taking over Tanzanian lands, of property being appropriated and women (the core small scale farmers) being stripped of their rights, were "thoroughly unjustified" (Palmer 1999, 4). Palmer's overall opinion was for Oxfam to monitor and observe developments. Over the intervening decade, it would seem that Issa's judgment has been vindicated. It remains to be seen to what extent and for how long ordinary people in Tanzania are content with the way events have unfolded and been arranged.

Up until this point, it needs to be recognized that Africa in general is highly volatile and that long term investments need very serious consideration as to factors that might influence outcomes negatively. In other words, Korean agricultural businesses would actively need to ensure that its very presence did not cause escalations of misunderstanding among indigenous societies. Big oil interests in Africa, for example, have tended to prefer African governments that responded favorably to their wants. However, the execution of the Nigerian poet Ken Saro-Wiwa was a public relations disaster for Shell Oil and Sani Abacha's government. It is an example of how not to do business in Africa. Given the risks, what then informs Korea's urgency in making bold moves in an area it has no real historical connection to?

\section{GENERAL IMPLICATIONS OF VENTURE AGRICULTURAL POLICY}

The immediate issue of food security for Korea needs to be put into perspective against remarks made by Korean farmers like Han Young Me of the Korean Women Peasants Association (GRAIN 2009, par. 1) who argued that Korean self-sufficiency in food production decreased in 2008 not because of commodity price increases but rather as a result of food rotting in Korean fields for lack of markets, even as government officials and businessmen were hurriedly securing international land deals. In other words, Korean farmers, it would appear, are becoming jeopardized by government policy that favors large scale industrialized growing, harvesting, processing, packaging and supply lines of food and food products. The value to the nation, and to Korean identity, of traditional farmers is becoming more emblematic than actual. Korean farmers would likely find more meaningful correspondence with Tanzanian peasant farmers who are similarly losing out to the future.

Korea's priority, however, seems to be to match China, Saudi Arabia, and other sovereign wealth states that have found it convenient to harness tracts of land abroad as a way of securing future food supplies. Again, this aim is 
not well described by the nature of the agricultural products Korean enterprises have advertised as its interests. The point is that Korea appears to have limited faith in its relations with existing agricultural product suppliers, such as the US, from which it is a large importer of grains and meat. Thus, where food security initiatives can be juxtaposed with business and military security issues, even among supposed allies, a new factor arises of how successful Korea's existing food suppliers may want the project to be. They can gain litcle benefit from seeing Korea achieve its land-lease ambitions and, possibly, become a future net food exporter. Korea, therefore, may need to factor in extra costs and oversight to secure the transport of supplies and products from Africa to its home markets. Ironically, Korea may be planning its food security around the idea of benign future relations with African countries and, on the other hand, ongoing volatile relations with North Korea. It could be that entirely different relations may be obtained in the near to mid- term. However speculative these points are, it remains that what Korea seems to be doing abroad and how it is going about these practices deserves more scrutiny and discussion than has been the case until now.

\section{RELEVANCE AND CONCLUSION}

While it is reasonable that Korean companies seek profits in new ways under adverse or volatile market conditions, and that a guiding concern may be to aid development in host nations abroad, such as in Tanzania, the problem lies in how such programs are implemented. In this paper, the Madagascan experience, the low-key disclosure of the Tanzanian project, actual PR announcements, questions about the contractual agreement terms, the limits to consultation, and the speed of implementation suggest that the manner of engagement is flawed and that problems are likely to result. These, however, are not the only issues.

As in the case of Korea's ODA profile, a less fragmented, more comprehensive framework for procedures and practices is required in order to forestall problems. One obvious issue perhaps not covered by the brief agreements in existence is pesticides (Lappé et al. 1998). Whereas the EU and the US have strict controls over what types, the methods of dispersal, and the amounts of such chemicals that may be used, this is likely to be highly unregulated in the new agricultural projects. The effects on local workers' health and lives could be severe and it is unlikely that they would be fairly informed by itinerant managers. In a related category, it must be asked to what extent Korea is bound to cater for ordinary and toxic waste disposal and, if responsible, what methods are structured for this purpose. Korea has experienced how difficult it is to get the US to pay for base closure costs after lease relinquishment. For the Tanzanians the potential to be "the victim of a victim" (The Economist 2003) of legacy costs imposed 
on them from outside is quite real.

Another issue relates to fertilizers, seed and ownership. It is possible that in the best case scenario the leasehold expires without mishap in 50 to 100 years. Afterwards, the land reverts to Tanzanian ownership. However, since it is almost certain that GM seeds will be planted in the region, the seed itself cannot be "owned" or renewably used by Tanzanian farmers without payments. Tanzanians may have to lease back or buy the seed for use on land that was itself nominally rented out for free.

A related question is asked by Lappé et al.(1998, 92): "what is food and who may have a claim to it?" It is relatively clear in South Korea that malnutrition is not a problem whereas food wastage is. One approach is for Korea to develop a complementary food security initiative in the domestic culture in which sufficiency rather than overindulgence becomes practice and policy. Korea's land reform acts following the Korean War resulted in a more widespread and just ownership arrangement. Korea could consider extending and exporting that basic concept of land reform to countries that need structural change. The results of exploiting loopholes and weaknesses in foreign land legislative arrangements may lead to tensions, produce greater inequality, and perhaps lead to conflict, none of which are desirable for a country in Korea's position. As a semi-peripheral (or semi-core) player in the global economy, Korea's status as a former colony of Japan and its power as a vibrant, newly industrializing nation of the digital age offer it formidable prestige. It must be asked whether Korea is willing to risk this standing on a sudden, speculative venture with unclear, real long-term costs and benefits.

One area of opacity relates to project redesignation. Where costs and benefits differ from initial projections, the guarantees and promises of either partner to a contract can change. The KRC is currently party in Korea to one such example of redesignation: the Saemangeum wetlands project. This wildlife habitat was developed for agricultural use. After construction of a massive sea wall, it was rezoned for business and industry, at the expense of a world-renowned nature sanctuary. It must be asked how the KRC could change its plans in Tanzania once deals are finalized, and what the potential costs might be.

Finally, the politics of principle that saw South Africa's apartheid system dismantled has shifted to the politics of such ambitious activities as "greening the planet". The momentum for this is building. In all likelihood, with the gradual securing of Indigenous People's rights globally, there will be resistance to whatever might be deemed neocolonialist practice in apparently malleable places. It is worthwhile for Korea to decide judiciously in this regard on what side of history it would like to stake its future claim. 


\section{REFERENCES}

Akira, Nakana. 2007. Korea's Railway Network the Key to Imperial Japan's Control. The Asia-Pacific Journal: Japan Focus. http://www.japanfocus.org/ -Nakano-Akira/2533.

Bates, Gill, Chin-hao Huang, and J. Stephen Morrison. 2007. Assessing China's Growing Influence in Africa. China Security 3(3): 3-21.

Brannigan, Augustine. 2007. The Genealogy of Genocide: Lessons From Rwanda. Paper Presented at the Annual Meeting of the American Society of Criminology. Atlanta Marriott Marquis. Atlanta, Georgia, November 14, 2007. http://www. allacademic. com/-meta/p201601_index.html.

Cotula, Lorenzo, Sonja Vermeulen, Rebeca Leonard, and James Keeley. 2009. Land Grab or Development Opportunity? Agricultural Investment and International Land Deals in Africa. London/Rome: IIED/FAO/IFAD. http://www.ifad.org/ pub-/land/land grab.pdf.

Fanon, Frantz. 2001. The Wretched of the Earth. Trans. Constance Farrington. Harmondsworth: Penguin Books Ltd.

Food and Agriculture Organization of the United Nation (FAO). 2009. From Land Grab to Win-W in. ftp://ftp.fao.org/docrep/fao/011/ak357e/ak357e00.pdf

GRAIN. 2009. Grabbing Land for Food. January 2009. http://www.grain.org/seedling/?id $=580$.

Haynes, Jeff. 2005. Resistance to Colonialism. In Encyclopedia of African History, ed. Kevin Shillington. New York: Fitzroy Dearborn: 1267-1277.

Hodgson, Dorothy L. and Richard A. Schroeder. 2002. Dilemmas of CounterMapping Community Resources in Tanzania. Development and Change 33: 79-100.

Kary, Tiffany. 2009. Daewoo Logistics Wins U.S. Bankruptcy Protections. Bloomberg. October 21.

http://www.bloomberg.com/apps/news-?pid = 20601127\&sid=aCiv7f.N3QT8

Kim, Eun Mee. and Jae Eun Lee. 2009. Policy Analysis of Korean ODA Effectiveness and Prescription for an Emerging Donor. Paper Presented at the KISA Workshop on East Asian Perspectives on the Legality and Legitimaty of the Use of Force. Seoul: Korea International Studies Association.

Kironde, J. M. Lusugga. 2000. Understanding Land Markets in African Urban Areas: the Case of Dar es Salaam, Tanzania. Habitat International 24: 151-165.

Lamb, David. 1982. The Africans. New York: Random House.

Lankov, Andrei. 2008. A Small Incident. Korean Times. January 3. http://www.koreatimes.co.kr/www/news/opinon/2009/10/165-_16638.html

Lappé, Frances Moore, Joseph Collin, and Peter Rossett. 1998. World Hunger: Twelve Myths. Oakland, California: Institute for Food and Development Policy. Lee, Tae Myeong. 2009. Nongeochongong, Tanzaniae Yeouido 120bae Nongeopdanjji. Hankuk Kyungjae. September 24. http://www.hankyung.com/news/ app/newsview.php?aid $=2009092477101$. 
Leigh, David, and Afua Hirsch. 2009. Papers Prove Trafigura Ship Dumped Toxic Waste in Ivory Coast. Guardian. May 14. http://www.guardian.co.uk/environment/2009/may/13/trafigura-ivory-coast-documents-toxic-waste:

London, Leslie. 1998. The 'Dop' System, Alcohol Abuse and Social Control Amongst Farm Workers in South Africa: a Public Health Challenge. Social Scence and Medicine, 48(10): 1407-1414.

Miller, Charles. 1974. Battle for the Bundu, the First World War in East Africa. New York: MacMillan Publishing Co., Inc.

Minten, Bart., Lalaina Randrianarison., and Johan F. Swinnen. 2005. Global Retail Chains and Poor Farmers: Evidence from Madagascar. World Development, 37(11): 1728-1741.

Moon, Katharine H. S. 2000. Strangers in the Midst of Globalization: Migrant Workers and Korean Nationalism. In Korea's Globalization, ed. Samuel Kim. New York: Cambridge University Press: 147-169.

National Bureau of Statistics (NBS), Ministry of Finance and Economic Affairs, the United Republic of Tanzania. 2008. Tanzania in Figures 2007. http://www.nbs.go.tz/TZ_FIGURES/TZ_FIG_2008.pdf

Palmer, R. 1999. The Tanzanian Land Acts, 1999: An Analysis of the Analyes. http://www.oxfam.org.mx/resources/learning/landrights/downloads/tananaly.rtf Said, Edward W. 1979. Orientalism. New York: Vintage Books.

See, Aie Balagtas. 2009. Senate Panel Inspects Hanjin Firm in Subic. GMA News. http://www gmanews.tv/story/147465/senate-panel-inspects-hanjin-firm-in-subic

TANServe Blog. 2009. Government Says No Land Deal with South Korea. http://tanserve.co.tz/2009/09/25/government-says-no-land-deal-with-south-korea/

The Economist. 2003. Edward Said (Obituary). 2003. http://www.economist.com/ obituary/displaystory.cfm?story_id=E1_NDJJGQP.

The United States Department of State-Bureau of African Affairs. 2009. Tanzania (08/09). http://www.state.gov/r/pa/ei/bgn/2843.htm.

Wallerstein, Immanuel. 1976. The Modern World-System: Capitalist Agriculture and the Origins of the European World-Economy in the Sixteenth Century. New York: Academic Press. 


\section{ENDNOTES}

As of 2005, the Overseas Korean Foundation estimates there to be 7,900 South Koreans living in 49 African countries; 238 of whom ate in Tanzania,

2Trio bid for 2018 Winter Olympic the British Broadcasting Corporatio (BBCInternet News. October 16, 2009.http://news.bbc.co.uk/sport2/hi/olympic games/8297329.st.

'See, for example, Leigh and Hirsch (2009) on the alleged dumping of toxic wastes on the Ivoryoast by a Swiss company.

- Madagascareaderxesandea TheBritish Bruadcasting Corporatio (BBC) Internet New. Mar 19, 200 http://news.bbc.co.uk/go/pr/fr/-/2/hi/atrica/7\%52628.st

Ibid.

'S Korea 'in Tanzania Land Deal.' heBritish Broadcasting Corporation (BBC) Internet News.September 24,009.http://new.bbc.co.uk/2/hi/8272506.st.

Specifically through the TANServe Blog, available at http://www.tanserve.co.tz/, and the Citizen Daily newspaper, available athetp://www,thecitizen,co,t2.

"S Korea 'in Tanzania Land Deal.' BBC. Ibid.

9 Saudi Investors Eye Leasing Tanzanian Farmlan. Reuter. April 16, 2009http://www.flexnews-food.com/pages/23214/Food/Saudi-Arabia/saudi-investors-eye-leasintanzaniafarmland.htm.

10 S Korea "in Tanzania Land Deal." BBC. Ibid.

11 The Treaty of Portsmouth, which was signed by Korea on November 17, 1905, effectively made Korea a protectorate of the Japanese cmpire. 